\title{
Potential Hazard of Open Space Fire in Black Pine Stands (Pinus nigra J.F. Arnold) in Regard to Fire Severity
}

\author{
Damir Barčić ${ }^{*}$, Tomislav Dubravac ${ }^{2}$, Marko Vučetić $^{3}$
}

(1) University of Zagreb, Faculty of Forestry, Department of Ecology and Silviculture, Svetošimunska 25, HR-10000 Zagreb, Croatia; (2) Croatian Forest Research Institute, Department for Silviculture, Cvjetno naselje 45, HR-10450 Jastrebarsko, Croatia; (3) Croatian Meteorological and Hydrological Service, Grič 3, HR-10000 Zagreb, Croatia

* Correspondence: e-mail: dbarcic@sumfak.hr

\begin{abstract}
Citation: Barčić D, Dubravac T, Vučetić M, 2020. Potential Hazard of Open Space Fire in Black Pine Stands (Pinus nigra J.F. Arnold) in Regard to Fire Severity. Southeast Eur for 11(2): early view. https:// doi.org/10.15177/seefor.20-16.

Received: 28 Jul 2020; Revised: 25 Oct 2020; Accepted: 8 Nov 2020; Published online: 4 Dec 2020
\end{abstract}

\begin{abstract}
Black pine (Pinus nigra J.F. Arnold) is one of the most important reforestation species for dry and rocky terrain in the subMediterranean zone. Fire is an important factor in black pine stands that largely defines the distribution range of black pine and the floristic composition of its stands. Fire causes less damage during autumn or early spring when tree cones contain ripe seeds that can partially reforest burnt surfaces. Every fire is a potentially significant threat to forest habitats. There are many damages, from direct damages to wood mass and reforestation costs, to indirect ecological, edaphic, protective damages and the loss of biological diversity. The aim of prevention works in forestry is to reduce the number of fires and reduce burnt surface area per fire. Research was based on vegetation analysis performed on each experimental plot in a black pine stand. The assessment of fire severity was performed using the Canadian Forest Fire Weather Index (FWI). The assessment of the severity of fire indicates the suitability of conditions for the occurrence of forest fires, and enables sound and effective protective methods beginning with silvicultural works. The results indicate better quality stands in the higher parts of the sub-Mediterranean area. Taking into account the climatic parameter, the areas on the border with the continental climate have better habitat conditions for black pine. Also, attention should be focused on 2012 and 2015. High values (Figure $13-16.22$, Figure $11-6.99$, Figure $8-8.38$, Figure $7-12.02$ and 12.25 , Figure $5-8.32$ ) indicate the overlapping of extremely dry periods and extremely high summer temperatures, and probably a strong wind influence that further increases the index. Fire severity assessments indicate the suitability of conditions for the onset of fire.
\end{abstract}

Keywords: forest fire; black pine; sub-Mediterranean; combustible materials; flammability

\section{INTRODUCTION}

In the sense of amelioration, black pine plays an irreplaceable role in processes that halt habitat degradation and the expansion of various forms of erosion. Black pine (Pinus nigra J.F. Arnold), as a reforestation species for karst landscapes, has been used throughout most of Northern Adriatic coast (the Istrian Peninsula and the Kvarner region). Particular success has been achieved during the work and establishment of the Supervision branch, as the Inspectorate for the Afforestation of Karst, Bare Rocky Grounds and Flood Control in the area of Senj on the north Adriatic coast (Ivančević 1978, 2003, 2005). Furthermore, black pine has been one of the fundamental afforestation species in the Dinaric karst area of Croatia during large forest raising projects (which started 150 years ago) by Croatian forestry (Martinović 2003). Black pine is one of the most important species for the afforestation of dry and rocky grounds in the sub-Mediterranean zone, and it is found most often on limestone and dolomite substrates. On rocky grounds under the influence of high winds, with poor stand conditions, it makes pure stands, while in more suitable habitats, indigenous deciduous species are a strong competitor and suppress its development. Since pine is a pioneer species that progressively colonizes abandoned and devastated habitats, particularly after the depopulation of 
those grounds and the cessation of anthropogenic activities (cutting, livestock husbandry), the indigenous deciduous species slowly regain their dominant role. Pine is suppressed and remains only in the most extreme habitats where there is no competition (Trinajstić 1979, Rauš et al. 1995). Fire is an important factor in black pine stands, which largely defines the distribution range of black pine and the floristic composition of its stands. Fire causes less damage if it occurs in autumn or early spring, when the tree cones contain ripe seeds that can partially reforest the burnt surfaces (Anić 1957). Though this is an extremely versatile species for amelioration, unlike other pines, it is often heavily affected by the fire season, with restoration and succession after fire as the primary concern. According to Retana et al. (2002), in the period between 1994 and 1998, an area of 40,420 hectares affected by fire in Catalonia recorded very poor regeneration with black pine as the dominant species. It is important to point out that fires in the Mediterranean are determined by climatic conditions (Carmel et al. 2009). Fire can be considered a natural element of the Mediterranean forest, determining its species composition and landscape structure (Trabaud 1994, González Olabarria 2006). Long, dry summers with high air temperatures reduce humidity in the forest floor layer to less than 5\% (FAO 2006), thereby increasing the ignition rate of combustible materials (Calabri 1990). These are usually open space fires; pursuant to the Firefighting Act (Official Gazette 106/99) and the Intervention plan for large open space fires (Official Gazette 25/2001), these are categorized as fourth- and fifth-degree fires. They include particularly valuable forest lands, exceptionally large open space areas, with a hazard index from high to very high. If there is a correlation of the ratio of fire frequency in the Mediterranean karst, lack of forestry and silvicultural works and poor potential for black pine regeneration, the situation becomes increasingly alarming. In that case, both the production (commercial) roles and general roles of black forests decline. Therefore, prevention works to protect forests from fire should be intensified in those areas and in those years when the assessment of fire severity is increased. This paper gives an overview of the assessment of fire severity in the sub-Mediterranean area where black pine stands are dominant. The aim of this paper is to point out the danger of open space fire in different conditions of the occurrence of black pine.

\section{MATERIALS AND METHODS}

Experimental plots were set up in black pine stands in the Istrian Peninsula and Kvarner (Hrvatsko primorje) regions. The selection of plots was defined on the basis of data from the Forestry Management Plan and reviews of geological, pedological and phytocenological maps. A range of factors was considered, such as stand age, human influence, microrelief, elevation, slope and insolation. Experimental plots were defined on an area of $625 \mathrm{~m}^{2}$ and stand structure research was conducted. Plots were set up in stands over 40 years old. For each plot, all black pine trees were measured by diameter class, number of trees, basal area and wood volume.
To calculate the amount of forest litter, 3 samples were taken along the diagonal of the experimental plot with an area of $25 \times 25 \mathrm{~m}$. All samples were dried at room temperature and then dried at $55^{\circ} \mathrm{C}$ in two measurements. Drying of the samples in each measurement took 48 hours, and the interval between the two measurements was at least one hour (UNECE 2004).

Of the fifty experimental plots, forty-three were planted in forest pine cultures, while seven plots were isolated in natural black pine stands. The investigated area includes the eumediterranean, sub-Mediterranean and epimediterranean vegetation zone. In the investigated area, a division was made according to altitude (up to $150 \mathrm{~m}$, from $150 \mathrm{~m}$ to $300 \mathrm{~m}$, and over $300 \mathrm{~m}$ above sea level).

The study area (Rab, Senj, Rijeka, Poreč, Pazin) is most represented by the Cfsax climate, according to Seletković and Katušin (1992). It is a moderately warm rainy climate with hot summers and average monthly temperatures above $22^{\circ} \mathrm{C}$. The winter rainy season is widely divided into spring and autumn-winter maximum. The driest part of the year occurs during the warm season.

Vegetation analysis was performed on each experimental plot, $625 \mathrm{~m}^{2}$ based on the plant sociology method (Braun-Blanquet 1964, Dierschke 1994). Species abundance and cover was assessed using the expanded scale according to Barkman et al. (1964). Prior to numerical analysis, all assessments were transformed into an ordinal scale according to van der Maarel (1979). Plant nomenclature was taken from Nikolić (1994, 1997, 2000). The association of environmental variables and floristic composition of vegetation was analysed using Canonical Correspondence Analysis - CCA (ter Braak 1986, Jongman et al. 1995, Gegout and Houllier 1996).

The assessment of fire severity was performed using the Canadian Forest Fire Weather Index (FWI). Fire Weather Index consists of five sub-indices. They take into account the daily variations of moisture in different fuels, which have different response time depending on weather conditions, initial propagation velocities, fuel quantities and expected intensity of fire front expansion. This index is a numerical assessment of the potential intensity of fire for a standard fuel type and is a relative measure of the expected fire behaviour and daily requirement for fire supervision (Van Wagner and Pickett 1985, Vučetić 2000,Vučetić and Dimitrov 2000, Vučetić 2001). The assessment of fire severity is considered the most appropriate indicator of the potential fire hazard.

\section{RESULTS}

A comparison of the vegetation zones clearly shows the differences between the sub-Mediterranean zones and the lower zones at the border between the eumediterranean and sub-Mediterranean zones. On the Istrian Peninsula and Kvarner region, black pine primarily grows on limestone, even though it is also found on flysch substrates. It is most widely distributed in the sub-Mediterranean vegetation zone where it is also the most important species for karst afforestation. 


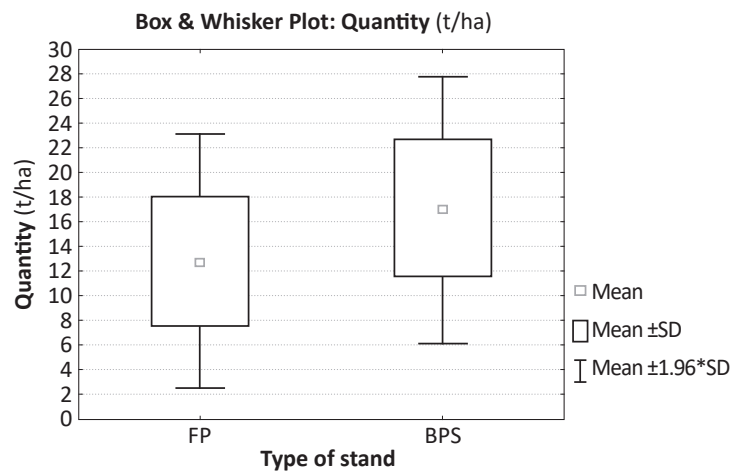

Figure 1. Quantity of forest floor (combustible matter) in forest plantations and natural black pine stands ( $F P=$ forest plantation, $\mathrm{BPS}=$ natural black pine stand).

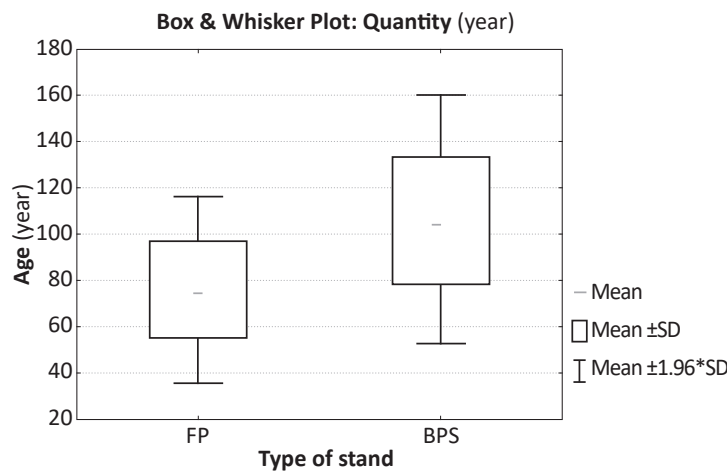

Figure 2. Age classification of natural stands (BPS) and forest plantations (FP) of black pine.

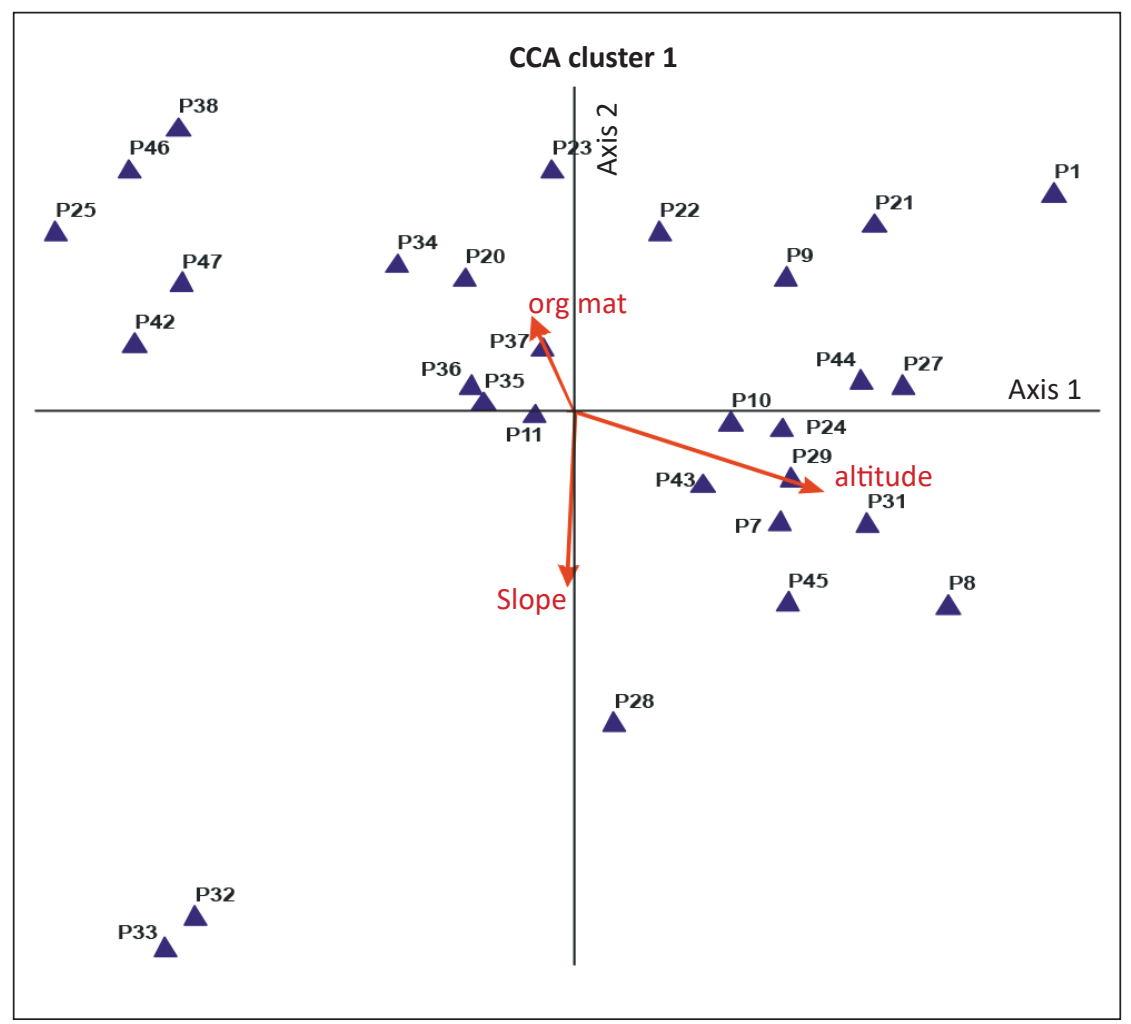

Figure 3. Canonical Correspondence Analysis (CCA) analysis of plot classification by elevation, slope and organic matter.

Table 1. Correlations according to Canonical Correspondence Analysis (CCA) analysis.

\begin{tabular}{llcc}
\hline \multicolumn{1}{c}{ Variable } & Axis 1 & Axis 2 & Axis 3 \\
\hline 1 organic matter & -0.145 & 0.444 & 0.427 \\
2 elevation & 0.845 & -0.378 & 0.145 \\
3 slope & -0.024 & -0.812 & 0.318 \\
\hline
\end{tabular}


The results indicate better quality stands in the higher parts of the sub-Mediterranean area. Taking into account the climatic parameter, the areas on the border with the continental climate have better habitat conditions for black pine.

Seasonal potential of fire severity indicates an increase in severity between 2007 and 2013, which is contrast to the researched period from 1997 to 2006, where the limit value of 7 is not exceeded. For Senj and Pazin, the values for 2012, 2013 and 2015 are extremely high, unlike values for Rijeka, Rab and Poreč, where only in 2012 the severity of fires exceeds the reference value of 7 (obtained by applying the Canadian method of the Meteorological Index of Forest Fire Hazards (Vučetić 2000), according to the results by Williams and Van Wagner in Dimitrov (1998). The decisive reason might be several days with strong winds in the circumstances of extremely dry and hot summer.
RAB

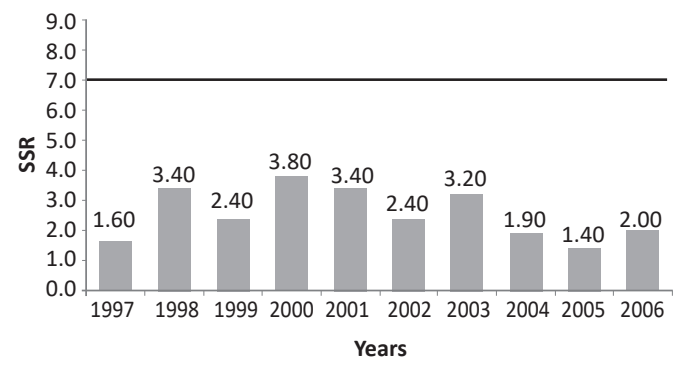

RAB

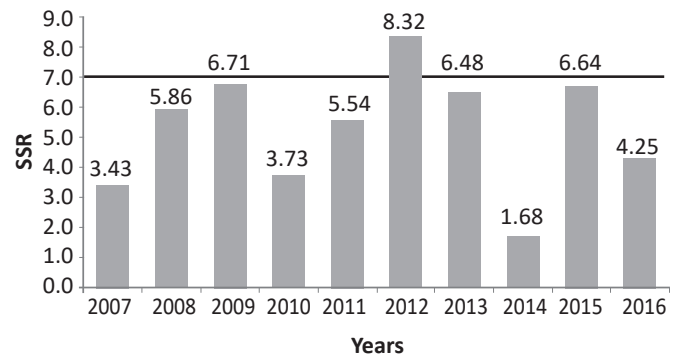

Figure 4. Seasonal potential of fire severity on the island of Rab (1997-2006, 2007-2016).

SENJ

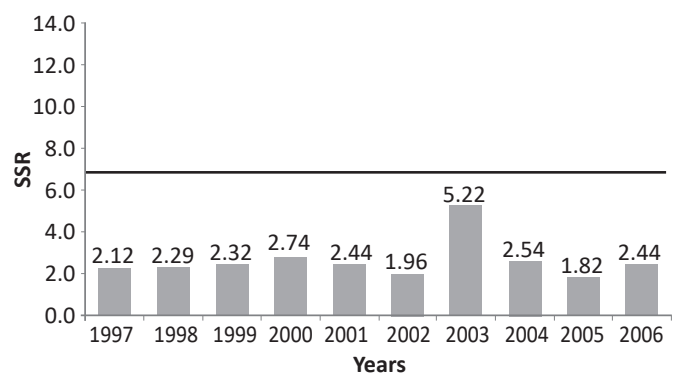

SENJ

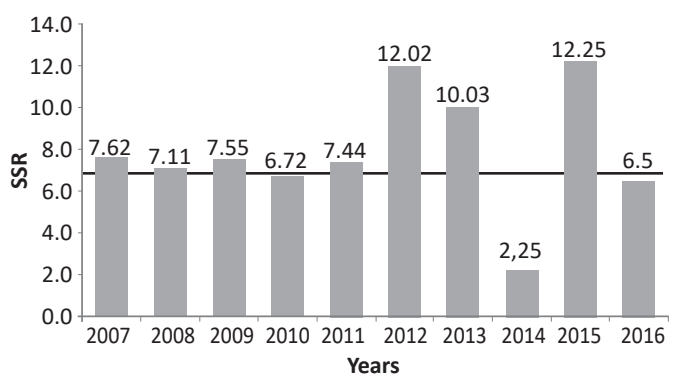

Figure 5. Seasonal potential of fire severity for Senj (1997-2006, 2007-2016).

RIJEKA

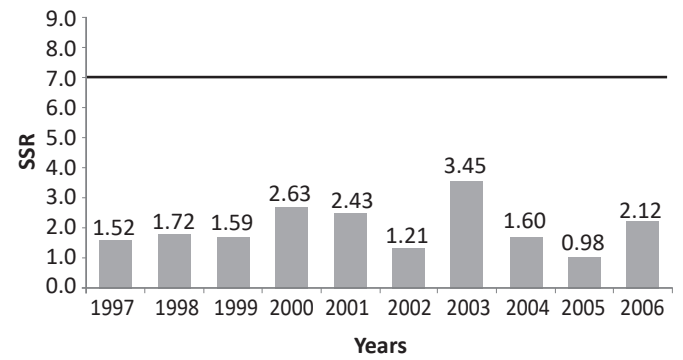

RIJEKA

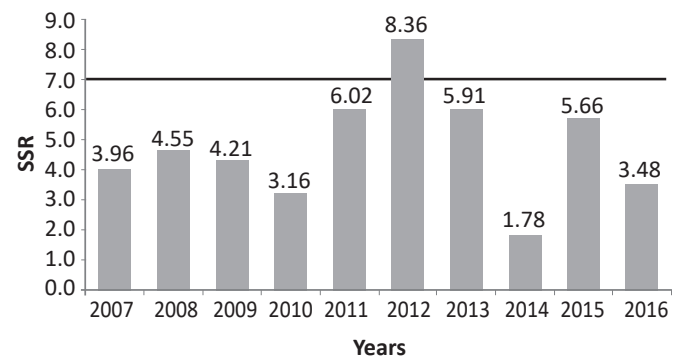

Figure 6. Seasonal potential of fire severity for Rijeka (1997-2006, 2007-2016). 
POREČ

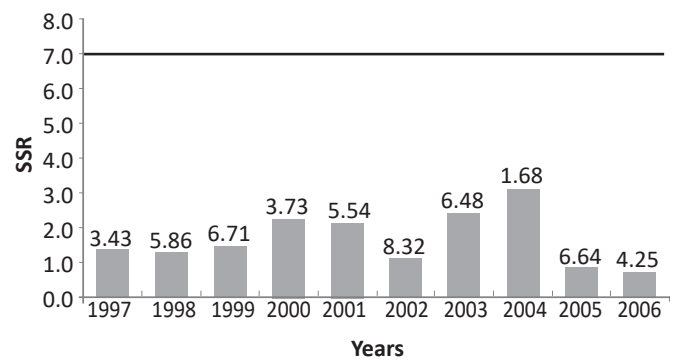

POREČ

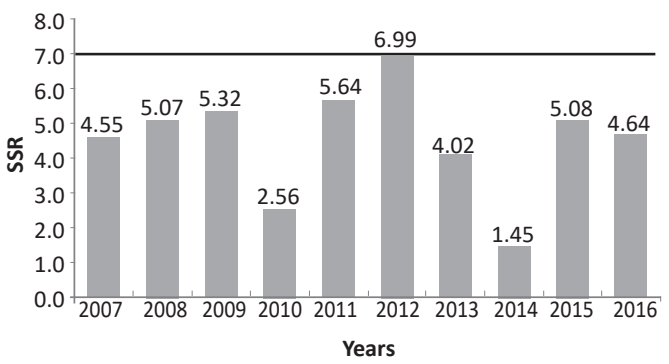

Figure 7. Seasonal potential of fire severity for Poreč (1997-2006, 2007-2016).

PAZIN

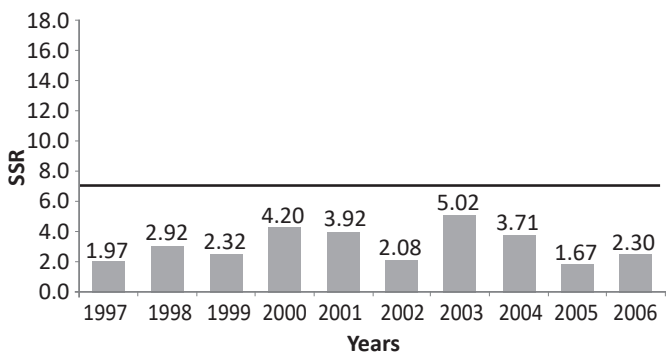

PAZIN

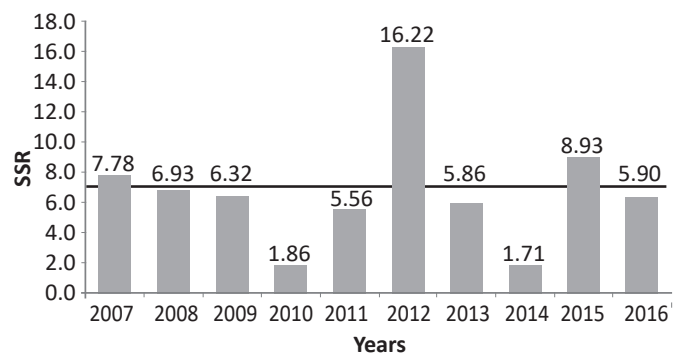

Figure 8. Seasonal potential of fire severity for Pazin (1997-2006, 2007-2016).

\section{DISCUSSION}

In the vegetation sense and in relation to fire hazard, black pine stands in the sub-Mediterranean zone are found in three elevation zones (low, mid and high). These zones in the study area are related to the proximity of the sea and the transition to continental climate. This is also the case in other Mediterranean countries (Gil and Aránzazu Prada 1993, Serrada Hierro, 1990, Grau Corbi et al. 1999). This zonation is related to higher quantities of precipitation at higher elevations. Habitat factors for black pine and other conifers in the Mediterranean have been observed through the prism of the Emberger pluviothermic quotient (Quézel 1976, M'Hirit 1999), as shown in Figure 9.

Weather and climate play a key role in the determination of the fire regime of an area, and the fire regime as such is very closely related to changes in climate (Kunkel 2001, Viegas et al. 2004, Pereira et al. 2005). The fire occurrence regime is characterised by its severity, rate of spread, summer season and frequency (Sousa 1984, Johnson and Gutsell 1994). In Croatia, research to date has warned that despite all efforts, the number of fires is increasing, as is the surface area affected (Rosavec et al. 2006, 2013). In the context of open space fire prevention, forest fire indices or danger assessment systems are used. The most commonly used is the Canadian system, called the Canadian Forest Fire Danger Rating System (CFFDRS), which consists of two subsystems: Fire Weather Index (FWI) and Fire Behaviour Prediction (FBP). This system has been applied in Croatia since 1981 (Mokorić and Kalin 2006). Though the climatic factor (temperature, precipitation) is important, since it is an integral factor in calculating potential severity, a large quantity of combustible materials is crucial for the spread and intensity of fire (Figure 1).

The first axis of the ordination scale is highly correlated with altitude. Overview of the correlations of variables is given below the graph (Figure 3). Taking into account pine stands and the relationship to environmental variables (Figure 2 and 3 ), the relationship to forest litter, altitude and slope is crucial. Litterfall intensity is strongly climate-dependent (Arneth et al. 1998, Starr et al. 2005). Among other factors, the age of the forest stand, species composition and density of trees also impact litterfall (Diaz-Maroto and Vila-Lameiro 2006, Starr et al. 2005). In our study, the correlation of forest litter depends on soil and plants' formation properties. Similar has been indicated in Banaszuk (2001) and Diaz-Maroto and VilaLameiro (2005).

Therefore, forestry and silviculture works are key in reducing the risk of forest fires, as these are the dependent 


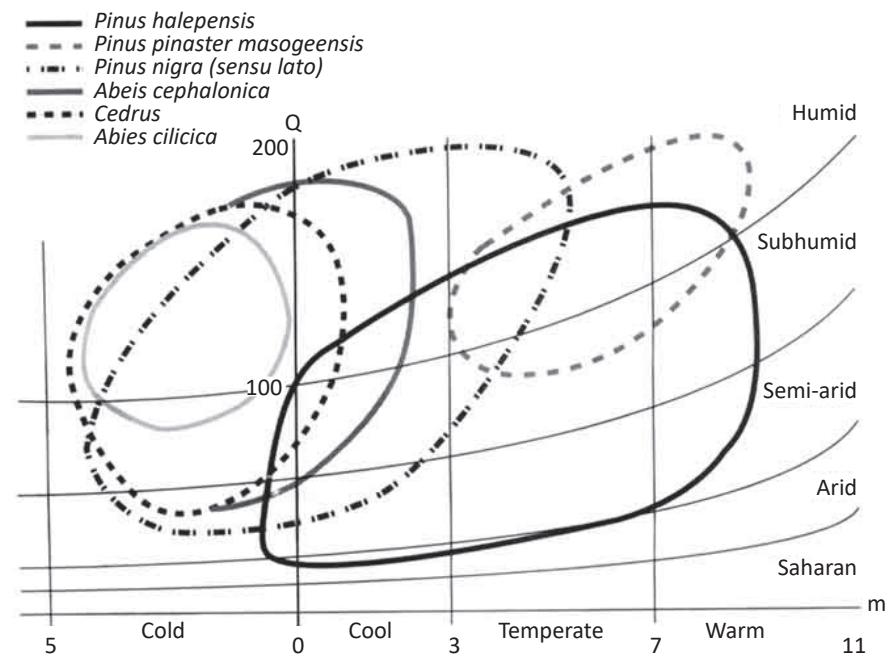

Figure 9. Climatic factors important for afforestation.

variables which can be altered. In the practical sense, and to minimize risk in raising black pine plantations, it would be useful to reduce the number of plants during afforestation works. Since afforestation typically uses a base of 2000 to 2500 plants per hectare (Meštrović and Fabijanić 1994), afforestation with 1000 to 1200 seedlings would result in a smaller scope of work in cleaning and thinning. Thinning in the plantations should begin between 25 and 30 years, and should be repeated every ten years. This would ensure a tree density of 500 trees per hectare at the end of the rotation (Bezak 1992). More intense thinning leaves only 140 trees per hectare, resulting in larger trees and the appearance of a range of deciduous tree species (Hamilton and Christie 1971). A 100-year old black pine tree (P. nigra ssp. laricio), as a commercial species, may have a wood volume of 450 $900 \mathrm{~m}^{3} \cdot \mathrm{ha}^{-1}$ and a density of 350-700 trees per hectare ( $C A B$ International 2000). The annual growth rate is about 4-6 $\mathrm{m}^{3} \cdot \mathrm{ha}^{-1}$, and between 7-10 $\mathrm{m}^{3} \cdot \mathrm{ha}^{-1}$ in the best habitats (Meschini and Longhi 1955, Bernetti 1995). Bernetti (1995) stated that in natural habitats, black pine has a wood volume of 150 to $450 \mathrm{~m}^{3} \cdot \mathrm{ha}^{-1}$. Analysis of its potential uses for burned timber and considering it in the economic optimizations could also offer a new perspective in this field of research (González Olabarria 2006). Ultimately, at the end of the rotation, there is a better chance of producing a higher quality stand, both in the production and ecological sense, with a lower amount of combustible matter.

According to Chandler et al. (1983) and Bilandžija (1992), combustible matter or forest fuel is the entire quantity of plant material, both dead and alive, which lies above the mineral layer of the soil. All aboveground vegetation is potential fuel, and vegetation types differ only in their flammability and burning rate under certain weather conditions. The combustible substance in the stand increases fire risk depending on stand structure and composition (González et al. 2006). According to the Canadian fire danger rating system (Van Wagner and Pickett 1985), combustible matter is classified on the basis of the size of the materials. Therefore, the system differentiates between the indicator of fine fuel moisture, the indicator of medium-sized solid fuel moisture, and the indicator of solid fuel moisture. The relationships between forest fires and the potential influence on vegetation is shown in the results of the seasonal intensity of fire danger (Figures 4 to 8). It is assumed for our research areas, and there are no empirically determined limit values in the researched area (Dimitrov 1998). Values above 7.0 are considered to represent exceptional fire severity. Values between 3.0 and 7.0 indicate high to very high intensity. Moderate severity includes values between 1.0 and 3.0. All values below 1.0 indicate low fire severity.

There is a prominent difference between the exceptionally dry year in 2003, and average precipitation years, such as 2005. Attention should be focused on 2012 and 2015. High values (Figure 8 - value 16.22, Figure 7 - value 6.99, Figure 6 value 8.36 , Figure 5 - values 12.02 and 12.25 , Figure 4 - value 8.32) indicate the overlapping of extremely dry periods and extremely high summer temperatures, and probably a strong wind influence that further increases the index.

Under such circumstances, the fire hazard in black pine stands is either reduced or increased depending on the annual climatic conditions. The aim of prevention works in forestry should be to reduce the number of fires and the surface area burnt per fire. Black pine currently has exceptional value in the ecological sense, such as its contributions to biodiversity in the karst landscape. According to the National Habitat Classification System and the Natura 2000 ecological network, and in line with the Ordinance on the list of habitat types, habitat maps and threatened and rare habitat types (Official Gazette 88/2014), the following are particularly valuable habitats. The priority habitat type $(* 9530)$ pertains to the (Sub-) Mediterranean endemic black pine forests (E.3.5.7.As. Ostryo-Pinetum nigrae (Anić 1957, Trinajstić 1998), 
E.7.4.4.- As. Cotoneastro-Pinetum nigrae (Ht. 1938), E.7.4.5. - As. Euphorbio triflorae-Pinetum nigrae (Ht. 1956, Trinajstić 1999), E.7.4.6.- As. Erico manipuliflorae-Pinetum dalmaticae (Trinajstić 1986) and E.7.4.7.- As. Junipero sibiricae-Pinetum dalmaticae (Domac 1962, 1965)).

\section{CONCLUSIONS}

Under the circumstances of increasingly frequent appearance of extremely dry and warm years, increased hazards for forest ecosystems can also be expected. Stands of black pine (Pinus nigra J.F. Arnold), as the most important species for afforestation of the sub-Mediterranean Dinaric karst, are particularly threatened. Anthropogenic influences should be applied through forestry and silvicultural work (cleaning and thinning) to maintain stand stability in the sense of quality and to reduce the quantity of combustible materials. Clearing the lower branches and ensuring fewer trees per hectare can reduce and limit the speed of spread of a forest fire, or the transition of a low fire into a high fire. With the assumption of good forest road openness, the ecological and commercial damages can be significantly reduced even in the appearance of a forest fire. Fire severity assessments indicate the suitability of conditions for the onset of fire. These values are calculated for the assessment of seasonal severity, which is an indicator dependent on the environmental conditions of a certain area. In this case, a 20-year period has been shown. However, in order to obtain more accurate insight into the severity assessment, monthly or daily danger assessments should be made during the fire season, or specifically for the summer months.

\section{Author Contributions}

DB and TD conceived and designed the review article. It is based on field measurements, data processing and statistical analysis performed by MV and DB. TD helped to draft the manuscript, DB wrote the manuscript.

\section{Funding}

This research received no external funding.

\section{Acknowledgments}

The authors would like to thank Croatian Meteorological and Hydrological Service, Agrometeorological Service and to Mario Ančić (Faculty of Forestry, Institute of Forest Inventory and Management) for technical support.

\section{Conflicts of Interest}

The authors declare no conflict of interest.

\section{REFERENCES}

Anić M, 1957. Crni bor u sjevernom Velebitu. Glas šum pokuse 13: 461-508

Arneth A, Kelliher FM, McSeveny TM, Byers JN, 1998. Net ecosystem productivity, net primary productivity and ecosystems carbon sequestration in a Pinus radiata plantation subject to soil water deficit. Tree Physiol 18: 785-793. https://doi.org/10.1093/ treephys/18.12.785.

Banaszuk P, 2001. Effect of habitat conditions on biomass production and nutrient cycling in communities of coniferous forest. Pol J Ecol 49(3): 271-298.

Barkman JJ, Doing H, Segal S, 1964. Kritische Bemerkungen und Vorschläge zur Quantitativen Vegetationsanalysen. Acta Bot Neerl 13(3): 394-419. https://doi.org/10.1111/i.1438-8677.1964. tb00164.x.

Bernetti G, 1995. Selvicoltura speciale. UTET, Torino, Italy, 416 p.

Bezak K, 1992. Tablice drvnih masa cera, crnog bora i običnog bora. Radovi 5: 47-65.

Bilandžija J, 1992. Prirodno opterećenje sastojina alepskog, primorskog i crnog bora šumskim gorivima. Radovi 27(2): 105113.

Braak ter CJF, 1986. Canonical correspondence analysis: a new eigenvector technique for multivariate direct gradient analysis. Ecology 67: 1167-1179. https://doi.org/10.2307/1938672.

Braun-Blanquet J, 1964. Pflanzensoziologie. Grundzüge der Vegetationskunde. $3^{\text {rd }}$ edn. Springer Verlag, Wien, New York, USA, 880 p.

CAB International 2000. In: Forestry Compendium (Global Module). Wallingford, Oxford, UK. Available online: https://www.cabi.org/ fc (18 November 2020).

Calabri G, 1990. Forest fires in Italy in 1989 and 1990. International Forest Fire News 4, 8 p. Available online: https://gfmc.online/iffn/ country/it/it_1.html (18 November 2020).
Carmel Y, Paz S, Jahashan F, Shoshany M, 2009. Assessing fire risk using Monte Carlo simulations of fire spread. For Ecol Manag 257(1): 370-377. https://doi.org/10.1016/i.foreco.2008.09.039.

Chandler C, Cheney P, Thomas P, Trabaud L, Williams D, 1983. Fire in Forestry, Volume 1: Forest Fire Behavior and Effects. $1^{\text {st }}$ ed. John Wiley \& Sons, Inc, New York, 450 p.

Diaz-Maroto IJ, Vila-Lameiro P, 2005. Seasonal evolution of soil chemical properties and macronutrients in natural forests of Quercus robur L. (in Galicia, Spain). Agrochimika 49: 201-211.

Diaz-Maroto IJ, Vila-Lameiro P, 2006. Litter production and composition in natural stands of Quercus robur L. (Galicia, Spain). Pol J Ecol 54(3): 429-439.

Dierschke H, 1994. Pflanzensoziologie. Grundlagen und Methoden. Verlag Eugen Ulmer, Stuttgart, Germany, 683 p.

Dimitrov T, 1998. Gorenje globalne biomase. Sumar list 122(9-10): 443-455.

FAO, 2006. Fire Management, Global Assessment 2006. Food and Agriculture Organization of the United Nations, Rome, Italy, 135 p. Available online: http://www.fao.org/3/A0969E/A0969E00.pdf (18 November 2020).

Gegout JC, Houllier F, 1996. Canonical correspondence analysis for forest site classification. A case study. Ann Sci For 53: 981-990. https://doi.org/10.1051/forest:19960506.

Gil L, Aránzazu Prada M, 1993. Pines as basic species for restoration of forests in the Mediterranean environment. Ecología 7: 113125.

González Olabarria JR, 2006. Integrating fire risk into forest planning. Academic Dissertation, University of Joensuu, Faculty of Forestry, Joensuu, Finland, 36 p.

González JR, Palahí M, Trasobares A, Pukkala T, 2006. A fire probability model for forest stands in Catalonia (north-east Spain). Ann For Sci 63: 169-176. https://doi.org/10.1051/forest:2005109. 
Grau Corbi JM, Camara Obregon A, Montoto Quinteiro JL, 1999. Site phytoclimatic aptitude for Pinus pinaster Ait., Pinus nigra Arn. and Pinus sylvestris L. Investigacion Agraria, Sistemas y Recursos Forestales 1: 37-51.

Hamilton GJ, Christie JM, 1971. Forest management tables. Forestry Commission Booklet No. 34, London, UK, 201 p.

Ivančević V, 1978. Posebne namjene šume crnog bora Senjske Drage. Master Thesis, University of Zagreb, Faculty of Forestry, Zagreb, Croatia, $94+26$ p.

Ivančević V, 2003. 125. obljetnica osnutka «Kraljevskog nadzorništva za pošumljenje krasa krajiškog područja - inspektorata za pošumljavanje krševa, goleti i uređenje bujica» u Senju (1878. 2003.). Sumar list Supplement 127: 3-22.

Ivančević V, 2005. Biološko-tehnički radovi na sanaciji senjske bujice "Torrente» i povećanje vodnog kapaciteta. Sumar list Supplement 129: 91-109.

Jongman RHG, Braak ter CJF, Tongeren van OFR, 1995. Data analysis in community and landscape ecology. Cambridge University Press, Cambridge. https://doi.org/10.1017/CBO9780511525575.

Johnson EA, Gutsell SL, 1994. Fire frequency models, methods and interpretations. Adv Ecol Res 28: 239-287.

Kunkel KK, 2001. Surface energy budget and fuel moisture. In: Johnson EA, Miyanishi $K$ (eds) Forest Fires-Behavior and Ecological Effects. Academic Press, San Diego, California, USA, pp. 303-350.

Maarel van der E, 1979. Transformation of cover-abundance values in phytosociology and its effect on community similarity. Vegetatio 39: 97-114. https://doi.org/10.1007/BF00052021.

Martinović J, 2003. Gospodarenje šumskim tlima u Hrvatskoj. Šumarski institut Jastrebarsko i Hrvatske šume d.o.o., Zagreb, $525 \mathrm{p}$.

Meschini A, Longhi, G, 1955. Le pinete di pino laricio. Loro conservazione e loro miglioramento. Atti del Congresso Nazionale di Selvicoltura. Accademia Italiana di Scienze Forestali, Florence, Italy, pp. 199-226.

Meštrović Š, Fabijanić G, 1994. Priručnik za uređivanje šuma. Ministarstvo poljoprivrede i šumarstva Hrvatske, Zagreb, 416 p.

M'Hirit O, 1999. El bosque mediterráneo: espacio ecológico, riqueza económica y bien social. Unasylva (FAO) 50(197): 3-15.

Mokorić M, Kalin L, 2006. Evaluation of meteorological index for forest fire protection in Croatia. For Ecol Manag 234: S70. https://doi.org/10.1016/j.foreco.2006.08.102.

Nikolić T, 1994. Index Florae Croaticae. Vol 1. Natura Croatica 3: Suppl. 2: 1-116.

Nikolić T, 1997. Index Florae Croaticae. Vol 2. Natura Croatica 6: Suppl. 1: 1-232.

Nikolić T, 2000. Index Florae Croaticae. Vol 3. Natura Croatica 9: Suppl. 1: 1-324.

Official Gazette NN 106/1999. Zakon o vatrogastvu. Zastupnički dom Hrvatskoga državnog sabora. Available online: /eli/ sluzbeni/1999/106/1759.

Official Gazette NN 25/2001. Plan intervencija kod velikih požara otvorenog prostora na teritoriju Republike Hrvatske. Vlada Republike Hrvatske. Available online: /eli/sluzbeni/2001/25/460.

Official Gazette NN 88/2014. Pravilnik o popisu stanišnih tipova, karti staništa te ugroženim i rijetkim stanišnim tipovima. Ministarstvo zaštite okoliša i prirode. Available online: /eli/ sluzbeni/2014/88/1782.

Pereira MG, Trigo RM, da Camara CC, Pereira JMC, Leite SM, 2005. Synoptic patterns associated with large summer forest fires in Portugal. Agr Forest Meteorol 129(1-2): 11-25. https://doi. org/10.1016/i.agrformet.2004.12.007.
Quézel P, 1976. Les Foréts du Pourtour Méditerranéen. In: Foréts et Maquis Méditerranéens Écologie Conservation et Aménagement. Note technique MAB 2, UNESCO Editions, Paris, France, pp 9-34.

Rauš Đ, Španjol Ž, Šikić Z, 1995. Sukcesija šuma crnog bora na trajnoj pokusnoj plohi br. 50 u NP Paklenica. Simpozij povodom 45. godišnjice NP Paklenica, Starigrad-Paklenica, Paklenički zbornik 1, pp. 119-128.

Retana J, Espelta JM, Habrouk A, Ordoñez JL, Solà-Morales F, 2002. Regeneration by sprouting of holm oak (Quercus ilex) stands exploited by selection thining. Vegetatio 99/100: 355-364.

Rosavec R, Španjol Ž, Barčić D, 2006. Sanacija opožarenih površina alepskog bora (Pinus halepensis Mill.) na području šumarije Dubrovnik. Glas šum pokuse 5: 167-178.

Rosavec R, Šikić Z, Španjol Ž, Barčić D, Vučetić M, 2013. Ugroženost sastojina alepskog bora (Pinus halepensis Mill.) požarima u stanišnim uvjetima jadranskog područja krša. Suma list 137(910): 461-471.

Seletković Z, Katušin Z, 1992. Klima Hrvatske. In: Rauš Đ (eds) Šume u Hrvatskoj. Šumarski fakultet Sveučilišta u Zagrebu i J.P."Hrvatske šume", Zagreb, Hrvatska, 340 p.

Serrada Hierro R, 1990. Considerations about reforestation impact in soils. Ecología 1: 453-462.

Starr M, Saarsalmi A, Hokkanen T, Merila P, Helmisaari HS, 2005. Models of litterfall production for scots pine (Pinus sylvestris L.) in Finland using stand, site and climate factors. For Ecol Manag 205(1-3): 215-225. https://doi.org/10.1016/i. foreco.2004.10.047.

Sousa WP, 1984. The role of disturbance in natural communities. Ann Rev Ecol Syst 15: 353-391.

Trabaud L, 1994. Post-fire plant community dynamics in the Mediterranean Basin. In: Moreno JM, Oechel WC (eds) The role of fire in the Mediterranean-Type Ecosystems. Ecological studies, Springer, New York, USA, pp. 1-15.

Trinajstić I, 1979. Osnovne karakteristike biljnog pokrova NP "Paklenica" u Hrvatskoj. Drugi kongres ekologa Jugoslavije, knjiga III, Zadar-Plitvice, pp. 77-88.

UNECE, 2004. Manual on methods and criteria for harmonized sampling, assessment, monitoring and analysis of the effects of air pollution on forests. Part XI, Sampling and Analysis of Litterfall, 18 p. Available online: https://www.icp-forests.org/ $\mathrm{pdf} /$ manual/2000/Chapt11 compl2004.pdf (18 November 2020).

Van Wagner CE, Pickett TL, 1985. Equations and Fortran Program for the Canadian Forest Fire Weather Index System. Canadian Forestry Service, Petawawa National Forestry Institute, Chalk River, Ontario. Forestry Technical Report 33, $18 \mathrm{p}$.

Viegas DX, Reis RM, Cruz MG, Viegas MT, 2004. Calibraçao do Sistema Canadiano de Perigo de Incendio para Aplicaçao em Portugal (Canadian Fire Weather Risk System Calibration for aplication in Portugal). Silva Lusitana 12(1): 77-93.

Vučetić $M, 2000$. Meteorološki indeks opasnosti od šumskih požara, Vatrogasni vjesnik 3, 38-40.

Vučetić M, Dimitrov T, 2000. Weather Conditions and Forest Fires in the Coastal Area of the Republic of Croatia During 1999. Sumar list 124(9-10): 549-560.

Vučetić $M, 2001$. Vremenske prilike i šumski požari na hrvatskom priobalju tijekom 2000. Sumar list 125(7-8): 367-378. 